\title{
EDITORS' MESSAGE
}

\author{
Clifford I. Voss, Editor \\ William E. Wilson, Technical Editor
}

Our new name. Readers may wonder if they have received the correct journal this month. Yes, we have a new name! At its meeting in Adelaide, Australia, the IAH Executive Council, upon recommendation of the Editors, approved a name change. After consideration of many options, the name Hydrogeology Journal was selected.

Hydrogeology is by nature an applied science. In this sense, use of the word "Applied" in the journal's former name was redundant. To some, "applied" suggested a limitation in the types of articles that would be published. Such a limitation was never intended. The journal's content has always been aimed at those developing the science of hydrogeology as well as those applying the science in practice. With its new name, our journal will continue in exactly the same spirit as was originally intended by its founders, but with an expected larger active readership and contributor base and greater recognition of its true scope.

The broad scope of the journal is reflected in the types of articles that are welcomed by the Editors. Included are presentations and discussions of new scientific results as well as reports describing regional or local hydrogeologic systems and groundwater concerns. Articles with interdisciplinary themes are particularly welcome. In addition, we seek accounts of phenomena observed at a field site, actual techniques applied to a particular practical problem, methodology development, and development of general principles of scientific hydrogeology.

The Editors encourage significant participation by hydrogeologists in developing countries. For example, Hydrogeology Journal will continue to be offered at a very low cost and with no page publication charges to authors. In addition, the journal provides support for editing of articles of non-native English speakers and for translation of accepted articles. We are striving to establish the shortest time between manuscript submission and publication of any major earth-science journal.

We anticipate that the new name, Hydrogeology Journal, and the scope that it implies will appeal to the widest possible group of professional hydrogeologists, practitioners of related subjects, and students. So, welcome to Hydrogeology Journal -- we hope you continue to like it!

Reviewers. For its technical soundness, the journal relies to a considerable degree upon the expertise and support of its reviewers. During 1994, the Editors called upon many colleagues to review articles submitted to the journal. Most of these volunteers remain as anonymous contributors to the complex process of preparing an issue of the journal. Therefore, the Editors take this opportunity to acknowledge and thank all the reviewers who contributed during 1994:

$\begin{array}{lll}\text { David Banks } & \text { Pierre Glynn } & \text { Joseph Pearson } \\ \text { Richard Cooley } & \text { Gunnar Gustafson } & \text { David Prudic } \\ \text { Judy Denver } & \text { John Kliever } & \text { Thomas Reilly } \\ \text { Alan Dutton } & \text { Nevin Kresic } & \text { Allan Rodhe } \\ \text { Jens Olaf Englund } & \text { Robert Nulson } & \text { Erik Rohr-Torp } \\ \text { Alan Flint } & \text { Roger Parsons } & \text { John Sharp, Jr. }\end{array}$

\author{
Ondrej Voborny \\ Alan Welch \\ Robert Wershaw \\ Thomas Winter
}

We look forward to working more with this group and with many others who have volunteered to serve as reviewers. If you would like to join the team, please contact the Editor, Clifford Voss.

The present Editors also extend grateful appreciation to John Moore and David Banks for assuming responsibility, as Guest Editors, for the first three issues of 1994. We are delighted, too, that David Banks has agreed to become our "re-Englishing" editor. As such, he will oversee the editing of manuscripts that have major language problems. 